\title{
Choice of Geographical Location as Governance Strategy in Outsourcing Contracts: Localized Outsourcing, Global Outsourcing, and Onshore Outsourcing
}

\author{
Anindita Chakravarty • Rajdeep Grewal • \\ Suprateek Sarker $\cdot$ V. Sambamurthy
}

Published online: 6 January 2014

(C) Springer Science+Business Media New York 2013

\begin{abstract}
Outsourcing, which involves business-to-business arm's-length exchanges with suppliers to supplement in-house activities, has grown internationally in scope with the advent of offshore outsourcing in which firms outsource business processes to be executed by suppliers in other countries. In spite of the dramatic growth in outsourcing, managerial governance concerns about controlling and coordinating suppliers' activities are prevalent. We propose that the geographic location (i.e., localized outsourcing, global outsourcing, and onshore outsourcing) from where the outsourced task is performed by the supplier should influence the degree of relational governance achievable, i.e., degree to which informal relationships and implicit norms of behavior are established among clients and suppliers. We apply transaction cost economics to suggest that depending on the degree of relational governance required for an outsourced task, firms might benefit by outsourcing the task to specific geographic locations. We use an event study to
\end{abstract}

Electronic supplementary material The online version of this article (doi:10.1007/s40547-013-0004-6) contains supplementary material, which is available to authorized users.

\footnotetext{
A. Chakravarty $(\bowtie)$

Terry College of Business, University of Georgia, Athens, GA, USA

e-mail: achakra@uga.edu

R. Grewal

Smeal College of Business, Pennsylvania State University,

University Park, PA, USA

e-mail: rgrewal@psu.edu

S. Sarker

McIntire School of Commerce, University of Virginia,

Charlottesville, VA, USA

e-mail: suprateek.sarker@comm.virginia.edu

V. Sambamurthy

Eli Broad School of Business, Michigan State University, East

Lansing, MI 48824, USA

e-mail: sambamurthy@bus.msu.edu
}

investigate shareholder perceptions of the mode of 185 outsourcing announcements of Fortune 500 multinational corporations during 1996-2004. The results from a model that accounts for the endogeneity of the choice of geographic locations show that for most outsourced ventures global outsourcing is a more effective relational governance strategy than onshore outsourcing or localized outsourcing.

Keywords Event study · Fortune 500 - Geographic location · Governance strategy $\cdot$ Multinational corporations .

Offshoring $\cdot$ Outsourcing $\cdot$ Transaction cost economics

Outsourcing of peripheral services comprises business to business ( $\mathrm{B}$ to $\mathrm{B}$ ) relationships and involves transferring organizational support functions to third-party suppliers through arm'slength contracts (e.g., [60]). The phenomenon of outsourcing has evolved to an extent that firms employ outside suppliers to fulfill almost all administrative and technical support functions ranging from customer support, accounting, and even taxbased services [34]. As an industry, outsourcing is estimated to garner up to $\$ 126.2$ billion of revenues by 2015 [55]. The $\mathrm{B}$ to $\mathrm{B}$ relationships involved in outsourcing are distinct from most B to B relationships studied in the marketing literature because outsourcing relationships involve a locational component such that outside suppliers may serve their clients from multiple international locations that require extensive crossborder interactions and coordination [4, 15]. Moreover, outsourcing B to B relationships involve arm's-length contracts (e.g., $[34,38]$ ) rather than ownership-based contracts such as joint ventures or full ownership that are studied in the marketing literature (e.g., [1, 30, 31]).

The predominance of arm's-length contracts creates cost efficiencies but involves enormous governance hurdles [36] because the outsourcing firm can neither govern by fiat [25] nor closely monitor the supplier's behavior [56]. Even though 
arm's-length contracts ideally would not require any governance on the part of the outsourcing firm due to market competition (i.e., supplier selection is competitive and market driven, which provides incentives for suppliers to perform), in reality the client firm has to coordinate with domestic and international suppliers (sometimes both) and control the quality of the service generated; thereby calling for some form of governance. The business press and academic literatures are replete with examples of outsourcing failures especially in international locations, wherein loss of managerial control and degeneration of service quality lead to either contract cancelation or contracts not being renewed [11, 49].

In this research, we study the governance problems of outsourcing firms and propose that the choice of the geographical location from where the outsourced task is performed by the supplier might address some of the governance issues. Specifically, we propose that as monitoring or governance by fiat are impractical in arm's-length outsourcing contracts, different degrees of relational governance, i.e., developing implicit norms of understanding and commitment with the third-party supplier to the extent required (e.g. [6]), is a feasible option. Our conversations with 16 managers responsible for outsourced ventures ${ }^{1}$ point to the strategic importance of establishing informal relationships with suppliers. Due to the relevance of relational governance in arm's-length contracts, we propose that managers should consider modes of outsourcing that represent different degrees to which effective relational governance may be achieved through the geographic proximity of the supplier's location to the client. The first mode is global outsourcing wherein a client requires a supplier to perform the outsourced task from both onshore (i.e., within the same country as the client) and from offshore locations. The second mode is the more traditional mode of localized outsourcing wherein a client requires a supplier to perform the outsourced task from an offshore location only. We also consider onshore outsourcing wherein a client outsources services to a supplier that performs the task only within the boundaries of the country in which the client operates.

To understand which mode of outsourcing (i.e., the extent of relational governance achievable) is best suited for a particular outsourced venture, we turn to transaction cost economics to outline the fit between an outsourcing mode and attributes of the outsourced venture in terms of task complexity, supplier-related uncertainty, and performance ambiguity (e.g., [52]). In line with the organizational contingency framework, we argue that the fit among outsourcing modes and attributes of outsourced ventures should determine the performance of the outsourced venture. For empirical validation of performance consequences, we use an event study and explore shareholder reactions to outsourcing announcements.

\footnotetext{
${ }^{1}$ We identified the 16 managers of different firms from Lou Dobbs's list of outsourcing firms and the participants of the OutsourceWorld conference held in New York in 2007, then interviewed them for 45-60 min each.
}

Shareholder reactions to firm-related events are often considered as market intelligence by managers, who consider stock price movements as valuable indicators of stakeholder perceptions about the firm (e.g., [40]). Event studies using shareholder reactions to public announcements made by firms have been used to understand the potential economic value of multiple strategic organizational decisions (e.g., [21, 42, 51]). A study of shareholder reactions, in the form of abnormal stock returns, thus provides a legitimate indication of the future economic value of managerial decisions, including the choice of outsourcing mode.

We organize the rest of this manuscript as follows: we first describe how different degrees of relational governance may be achieved through the three modes of outsourcing. Then, we align each attribute of the outsourced venture with a mode of outsourcing that best meets the relational governance demands of that attribute to develop our hypotheses. Subsequently, we present the event study methodology and results; we then conclude with a discussion of the study results, limitations, and contributions.

\section{Theory}

\subsection{Modes of Outsourcing}

A complex phenomenon, outsourcing entails multiple modes that reflect the geographic location from which a supplier implements its task on behalf of a client. From business press reports about outsourcing, we derive descriptions of the three most prevalent modes of outsourcing: localized, global, and onshore outsourcing.

Localized outsourcing involves transferring business transactions to foreign nations [5, 17]; in 2003, Bear Stearns reported that it had chosen Satyam Computer Services to implement a significant portion of its information technology operations from India. Global outsourcing refers to ventures in which the supplier implements the outsourced venture from both onshore and offshore locations, relative to the client (e.g., [53]). Thus, the announcement by Hospital Corporation of America that it was transferring its application maintenance and enhancement support services to Syntel, which would manage these services from both Nashville, Tennessee, and Hyderabad, India, represents a dual onshore and localized outsourcing scenario. A common variation of global outsourcing observed in practice involves the allocation of different aspects of a large outsourced job to the supplier's various locations in multiple countries, depending on the competencies, capacities, and cost structures of those different locations [53]. In onshore outsourcing, suppliers work in the same country as the client organization. For example, in 2001, Comcast Corporation (client) publicly announced that Unisys (supplier) would manage its remittance-related transactions 
from the latter's Pennsylvania service center; thus, though Comcast transferred this business transaction beyond its firm boundaries, the transaction continued to be implemented within the borders of the same country in which Comcast operates.

\subsection{Comparison of Outsourcing Modes}

We compare the modes of outsourcing in terms of the extent of relational governance achievable through each. Other mechanisms, such as output or behavior monitoring, exist, but they tend to be insufficient or infeasible in arm's-length contracts. Tasks differ in the degree to which their output can be quantified (e.g., [50]), and the threat of supplier opportunism rarely is limited to just the output generated [39], such that the client needs confidence in the supplier's overall intentions, beyond output [13]. Furthermore, the absence of any formal hierarchical authority between the client and supplier makes behavioral monitoring not only difficult [10] but also prone to misunderstanding and distrust [18]. Therefore, we focus on relational governance instead, for which the absence of hierarchical authority actually creates opportunities to promote social processes in which suppliers may choose to (rather than being told to) participate (e.g., [7]).

The social processes embedded in relational governance involve repeated, personal interactions, travel to supplier sites, and extensive sharing of explicit and tacit information. The development of relational ties thus implies dedicating time and resources to informal exchanges, mutual collaboration, and communication about implicit expectations of reciprocity and longevity [37, 45]. The location of the supplier (i.e., mode of outsourcing) has a significant influence on the efficiency with which the social processes of relational governance can be enacted.

Localized outsourcing involves considerable hazards due to the geographical, cultural, political, and legal distances between a client and a supplier [27, 29, 44]. The transfer of employees between client and supplier locations may be cumbersome, due to legal concerns such as immigration regulations. Information exchange also may be ineffective due to differences in languages or cultural norms. Because of differences in regulations related to trade, taxation, capital movements between client and supplier countries, the possibilities that operations may be disrupted and contracts reneged on as a result of governmental policy shifts are considerable (e.g., [23, 48]). Localized outsourcing thus may not be able to effectively facilitate relational governance. In contrast, with onshore outsourcing, the presence of both client and supplier in the same country should facilitate their quick establishment of joint teams, task forces, and committees that regularly visit the supplier sites and share a common language without cultural barriers. The common umbrella of a single legal and political system fosters the willingness of both parties to invest in long-term trust-building measures that are not subject to volatile changes or the interference of foreign governments [28]. Thus, we anticipate the scope for relational governance in onshore outsourcing to be more than in localized outsourcing.

As the hybrid form, global outsourcing facilitates relationship building with the supplier through the onshore location, but the simultaneous presence of offshore task implementation might create challenges related to interpersonal interaction, open communication, and politically or legally induced disruption of informal relationships. In terms of relational governance, global outsourcing thus should be less effective than onshore outsourcing but more effective than localized outsourcing.

\subsection{Aligning Outsourcing Modes with Attributes of the Outsourced Venture}

Because outsourcing relies on contracts, we turn to theories of contractual exchange, specifically transaction cost economics, to develop a set of attributes that likely are relevant to the outsourced venture. Transaction cost economics suggests that asset specificity and uncertainty determine governance mechanisms. We thus define three broad attributes of an outsourced venture: task complexity, supplier-related uncertainty, and performance ambiguity. Task complexity incorporates notions of asset specificity, supplier-related uncertainty refers to perspectives on insufficient information about supplier motivations and capabilities, and performance ambiguity builds on the lack of quantifiable metrics to measure task outcomes.

\subsection{Task Complexity}

For a client, an outsourced task becomes more complex as it becomes increasingly embedded in a network of organizational procedures with a multitude of processes and entities. The complexity of the task warrants the deployment of resources uniquely configured to facilitate interactions and data exchanges among multiple organizational processes and entities. In a sense, as task complexity increases, the resources become less redeployable to other tasks. The uniqueness of the resources dedicated to the task increases switching costs and might make the client vulnerable to opportunistic supplier behaviors (e.g., [2]). As task complexity increases, the client's need for relational governance increases too, as a means to engender supplier trust and reciprocity and thus protect the client's investments in specialized resources.

These requirements for higher relational governance mean that as task complexity increases, onshore outsourcing should represent the most desirable option, because of the supplier's closer proximity, which facilitates cost-effective, informal relationship building. However, between global and localized outsourcing, we anticipate a preference for the former, because of the substantial onshore presence of the supplier in global outsourcing. This onshore representation in global outsourcing provides a degree of supplier contact and 
familiarity that localized outsourcing cannot provide. Thus, as task complexity increases, shareholders should prefer onshore outsourcing most and localized outsourcing least.

Hypothesis 1 As task complexity increases, the abnormal stock returns associated with the outsourced venture are higher for (a) onshore outsourcing than for localized outsourcing, (b) onshore outsourcing than for global outsourcing, and (c) global than for localized outsourcing announcements.

\subsection{Supplier-Related Uncertainty}

Supplier-related uncertainty refers to a client's inability to gauge a supplier's potential behavior ex ante (i.e., during supplier selection) or ex post (i.e., after the contract has been signed and the outsourced venture is operational).

\subsubsection{Ex ante Uncertainty}

At the time of supplier selection, supplier-related uncertainty reflects a client's lack of knowledge about a supplier's intentions and competencies (e.g., [33]). A high level of supplierrelated uncertainty could lead to an adverse selection problem, such that the client must select a supplier based on incomplete information (e.g., [3]), which increases the risks of supplier opportunism and raises the potential for poor task performance (e.g., [59]). Increasing supplier-related uncertainly thus demands a governance mechanism that engenders a sense of obligation in the supplier to deliver as promised. The governance mechanism should allow the client to interact with and visit the supplier frequently to keep track of the supplier's actions without formally enforcing behavioral monitoring. We operationalize ex ante supplier-related uncertainty in terms of prior relationships.

Specifically, prior relationships with a bidding supplier enable a client to develop an understanding of the supplier's trustworthiness, competence, and limitations when bidding for service agreements. Familiarity born from these prior relationships produces a common language that reduces uncertainty about potential supplier behaviors [19]. Suppliers have a "tendency 'to paint a rosy picture' to clients" initially, and because of the intangible nature of some of their capabilities, they are "difficult to quantify and assess," which makes past relationships useful in this context ([57], p. 77). As the number of prior relationships with a bidding supplier increases, the client's uncertainty about the supplier should decline, which increases the client's confidence in selecting this supplier for an outsourcing venture. The need for further investments in relational governance processes accordingly should decline.

Because the three modes of outsourcing involve different degrees of relational governance, we predict that as prior relationships increase, the need for governance through active relationship building decreases, and, as a result, the mode of outsourcing matters less. In this case, transaction efficiencies may be facilitated more by production efficiencies than by governance mechanisms. After all, cost savings are often one of the primary reasons for arm's-length outsourcing contracts (e.g., [22]) especially if the outsourced task involves administrative and technical services (e.g., [34]). Therefore, as ex ante supplier uncertainty decreases, the most feasible mode of outsourcing may be dictated by production efficiencies rather than governance-related concerns. In terms of production efficiencies, localized outsourcing should be the most preferred option, because implementing outsourced operations in foreign locations (typically developing economies) generally facilitates access to low-cost labor and skills and wage arbitration opportunities. The cost reduction opportunities are less prominent for global outsourcing, whereas they are nonexistent with onshore outsourcing, because the lack of offshore implementation means the client lacks access to lowcost opportunities. Thus, as ex ante supplier-related uncertainty decreases, shareholders should reward localized outsourcing the most and onshore outsourcing the least:

Hypothesis 2 As ex ante supplier-related uncertainty decreases, abnormal stock returns associated with the outsourced venture are lower for (a) onshore outsourcing than for localized outsourcing, (b) onshore outsourcing than for global outsourcing, and (c) global outsourcing than for localized outsourcing announcements.

\subsubsection{Ex Post Supplier-Related Uncertainty}

We define ex post supplier-related uncertainty, which we operationalize as the length of the outsourcing contract, as the extent to which the outsourced venture may be exposed to opportunistic supplier behavior, once the venture is operational. As contract length increases, a supplier's familiarity with a client's business increases, which should grant the supplier greater access to proprietary information and tacit learning about the client's internal processes (e.g., [32, 61]). In addition, the possibility that a client may need to reconfigure strategic processes in the long term and adapt the terms of the contract to align strategic processes with environmental changes increases with longer contract length (e.g., [35]). Long-term contracts must be flexible to accommodate future adaptations and make future contract renegotiations cost effective $[12,41]$, so with longer contract length, perhaps purposefully incomplete (flexible) contractual guidelines generate future opportunities for the supplier to renege and drive costly bargains. To ensure that the client retains contract flexibility but also can prevent supplier opportunism, clients should develop close relationships with suppliers based on mutual trust, commitment, and willingness to adapt [16]. Overall, as contract length increases, ex post supplier uncertainty increases, which increases the demand for an 
outsourcing mode that can facilitate close, informal interactions, and cooperative behaviors. We therefore propose that due to their physical proximity implications, onshore outsourcing is the most and localized outsourcing is the least appropriate mode.

Hypothesis 3 As ex post supplier-related uncertainty increases, abnormal stock returns associated with the outsourced venture are higher for (a) onshore outsourcing than for localized outsourcing, (b) onshore outsourcing than for global outsourcing, and (c) global than for localized outsourcing announcements.

\subsection{Performance Ambiguity}

Performance ambiguity constitutes the client's inability to quantify the task outcomes of the outsourced venture (e.g., [14]). A client's goal for outsourcing determines the outcome that must be measured. As the degree of intangibility of outsourcing goals increases, the extent to which task outcomes can be reliably quantified decreases. For a goal such as quality enhancement, the task outcome is abstract and cannot be measured easily, which increases a client's concerns about the outsourced venture $[9,46,58]$. Such high-performance ambiguity requires the client to interact repeatedly with the supplier and establish a mutual commitment to cooperative behavior - that is, it demands increased relational governance. With this demand, increased performance ambiguity should make supplier proximity more important. We thus propose that shareholders value onshore outsourcing most and localized outsourcing the least.

Hypothesis 4 As performance ambiguity increases, the abnormal stock returns associated with the outsourced venture are higher for (a) onshore outsourcing than for localized outsourcing, (b) onshore outsourcing than for global outsourcing, and (c) global than for localized outsourcing announcements.

We summarize our hypotheses in Fig. 1, which also includes the dependent, independent, and moderating constructs and their proposed relationships.

\section{Method}

\subsection{Data and Variable Operationalization}

We collected outsourcing announcements by Fortune 500 multinational corporations from the Factiva database; in so doing, we

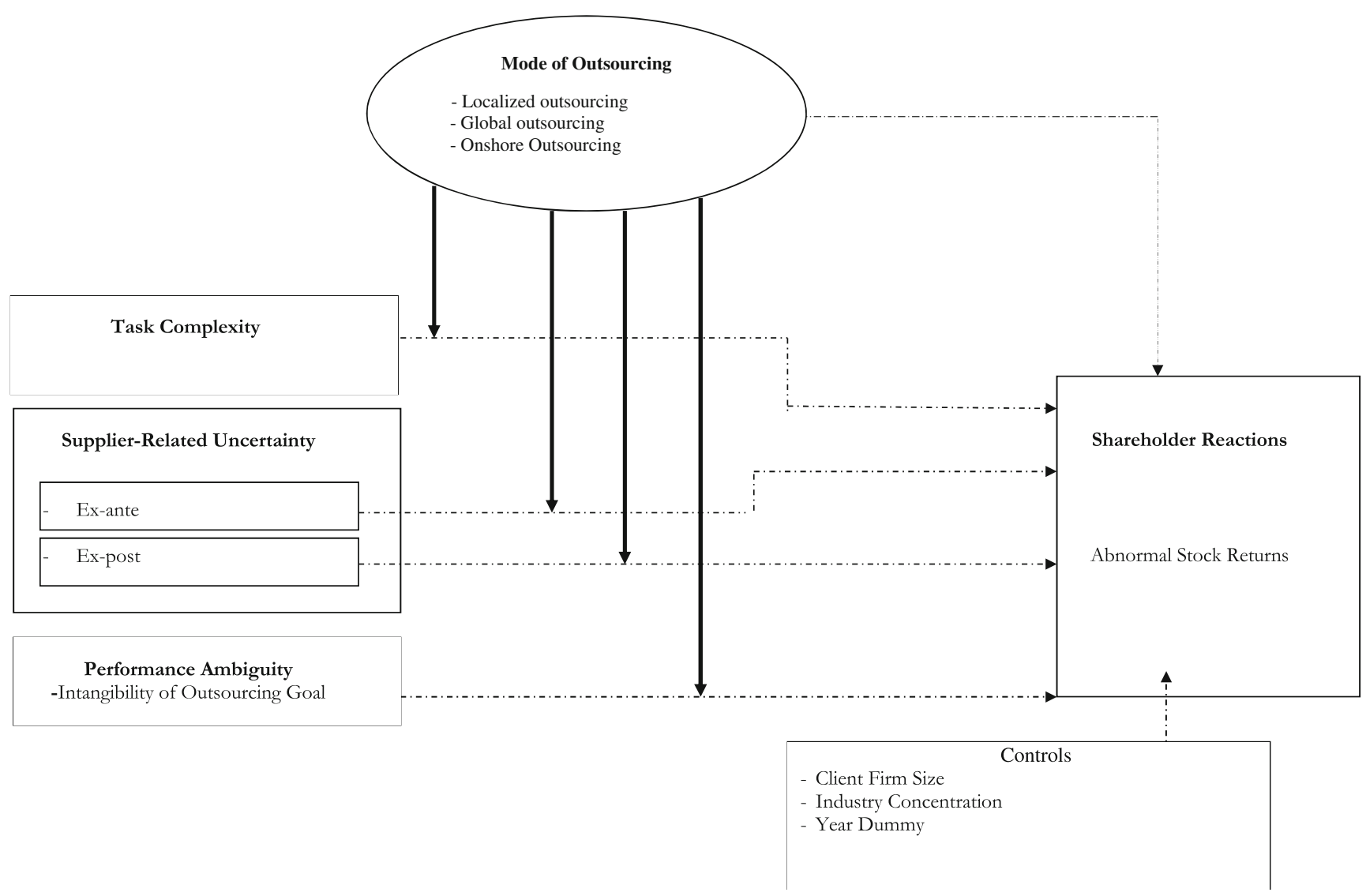

Fig. 1 Conceptual framework 
ensure the client firms are big enough to have the potential for global operations. We collected announcement information in the following manner. To investigate all three modes of outsourcing to third-party suppliers (localized, global, and onshore), we determined common terms used to describe the overall phenomenon of outsourcing through a review of articles in the business press. We selected the earliest announcement of an outsourced venture for any company in a particular year [26], After screening the announcements, ${ }^{2}$ we retained 185 outsourcing announcements during 1996-2004 that represented 49 onshore outsourcing, 65 localized outsourcing, and 71 global outsourcing announcements. Independent sample tests for the equality of means ( $t$ tests) of the three outsourcing samples reveal no statistically significant differences across the three groups in terms of liquidity ratios, returns on assets, net income growth, or gross revenues. Approximately $24 \%$ of outsourcing announcements involved firms in the financial services, insurance, or commercial banking industries; approximately $27 \%$ came from firms in the retailing, energy, and utilities industries; $3 \%$ were by business and consulting firms; and the remaining $46 \%$ of announcements were made by firms in manufacturing industries.

We describe the variable operationalizations (including moderators) and offer some examples of outsourcing announcements in Table $1 .^{3}$ We present the descriptive statistics in Table $2 .{ }^{4}$

\subsection{Measuring Shareholder Reactions as Abnormal Stock Returns}

Consistent with the event study methodology, we calculate abnormal stock returns (i.e., dependent variable) over an event

\footnotetext{
${ }^{2}$ We initially obtained 490 outsourcing announcements. We screened them by deleting any that contained general outsourcing discussions. Using an event window of 3 days prior to and after the date of each announcement, we searched for announcements on all possible topics about the focal company, then excluded any announcements whose event period contained disclosures related to mergers and acquisitions, spinoffs, stock splits, CEO or CFO changes, layoffs, restructurings, or earnings, as is the recommended practice for event analysis [40].

${ }^{3}$ We control for client firm size because larger firms, with their greater resources relative to smaller firms (e.g., [43]), may be able to devote more resources to governing outsourced ventures and therefore better influence shareholder perceptions of outsourcing productivity. We also control for industry concentration; in an industry with high concentration, a few firms maintain extensive market share, so the incremental competitive benefit of one outsourced venture to each firm may be less than the benefits that accrue to the many struggling firms in an industry with low concentration. Thus, shareholders may value an outsourced venture differently depending on the industry concentration. We also account for the time of outsourcing by incorporating year-specific dummy variables.

${ }^{4}$ Our choice of theoretical constructs was limited to data available in public outsourcing announcements. According to an event study methodology, shareholders should respond only to information available in public sources. Most details about an outsourced venture are limited to the information that either the client or the supplier publicly announces, so by relying on outsourcing announcements, we should be able to tap the information that shareholders possess and act on. This approach is consistent with prior event study research (e.g., [21]; [51]).
}

window surrounding the day of the actual announcement, using the cumulative abnormal returns (CAR; operationalized using three methods - see Appendix) and buy-and-hold abnormal returns (BHAR). Thus, we obtain two separate measures of abnormal stock returns, which we can use to crossvalidate our results. Both CAR and BHAR are common in event studies [40]; we provide details on these two measures in the Electronic Supplementary Material (ESM) Appendix.

We build a regression model to test our hypotheses. Although we provide complete details of our regression model in the ESM Appendix, we highlight that we make modifications to our basic regression equation for two reasons. First, since we do not know whether Fortune 500 firms without outsourcing announcements differ systematically from those with outsourcing announcements during the study period, we need to correct for sample selection bias, which if not accounted for could distort parameter estimates. As recommended by [24], we use the inverse mills ratio from the Heckman's selection procedure as a correction term in our basic regression model [20]. Second, we correct for endogeneity because the independent variables in our regression model, modes of outsourcing, are strategic choices by managers that likely depend on several factors. As a result, shareholders could be reacting to the factors leading to the choice of a mode of outsourcing rather than the mode of outsourcing itself. Because the modes of outsourcing are coded as binary variables, the most feasible endogeneity correction is the instrumental variable approach as prescribed by [24], which involves a probit model as the first step followed by derivation of the inverse mills ratio to be included in the basic regression model.

\section{Results}

For each attribute (i.e., task complexity, ex ante supplierrelated uncertainty, ex post supplier-related uncertainty, and performance ambiguity), we examine the comparative effects of the three outsourcing modes on abnormal stock returns. In the aggregate data with all three modes, the mean CARs and BHARs are consistently statistically significant for the event window $(0,+1) .{ }^{5}$ We therefore use the abnormal returns for

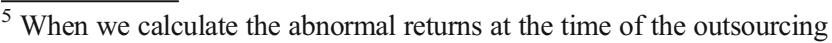
announcements, we find in the case of localized outsourcing announcements, the results over a 2-day event windows are negative and statistically significant (mean CAR $(0,+1)=-0.56 \%$, generalized $\operatorname{sign} z=-1.98$; mean BHAR $(0,+1)=-0.56 \%$, generalized sign $z=-1.99$. In the case of onshore outsourcing, results over a 2-day event windows are negative and statistically significant (mean CAR $(0,+1)=-0.61 \%$, generalized sign $z=-2.11$; mean $\operatorname{BHAR}(0,+1)=-0.60 \%$, generalized $\operatorname{sign} z=-2.03)$. The results for global outsourcing are statistically significant but positive over a 2-day event window (mean CAR $(+1,+2)=$ $0.47 \%$, generalized sign $z=2.21$; mean $\operatorname{BHAR}(+1,+2)=0.48 \%$, generalized sign $z=2.20$ ).
} 
Table 1 Variable operationalization

\begin{tabular}{|c|c|c|c|}
\hline Variable & Variable description & Coding & Relevant examples \\
\hline Localized outsourcing & $\begin{array}{l}\text { Work is not performed in same nation as client. } \\
\text { Some portion or all of the work is performed } \\
\text { in same nation as client. }\end{array}$ & $\begin{array}{l}1 \\
0\end{array}$ & $\begin{array}{l}\text { In 2003, Bear Stearns reported a 3-year contract with its } \\
\text { selected supplier Satyam Computer Services to operate } \\
\text { computer maintenance services completely from India } \\
\text { (coded 1). }\end{array}$ \\
\hline Onshore outsourcing & $\begin{array}{ll}\text { Entire work is performed in same nation as client. } & 1 \\
\text { Entire work is not performed in same nation } & 0 \\
\text { as client. } & \end{array}$ & $\begin{array}{l}1 \\
0\end{array}$ & $\begin{array}{l}\text { In 2001, Unisys Corporation announced it would manage } \\
\text { remittance payments for Comcast Cable from its } \\
\text { Pennsylvania service center for } 6 \text { years and open a } \\
\text { second facility in Washington (coded 1). }\end{array}$ \\
\hline Global outsourcing & $\begin{array}{ll}\text { Work is performed in the same nation as client } & 1 \\
\text { and in foreign location. } & \\
\text { Work is performed exclusively onshore or offshore. } & 0\end{array}$ & 1 & $\begin{array}{l}\text { In 2001, HCA, a healthcare services provider in the USA, } \\
\text { announced it was transferring IT application } \\
\text { maintenance and enhancement support services to } \\
\text { Syntel, which would manage services from Nashville, } \\
\text { Tennessee, and Hyderabad, India for } 5 \text { years (coded 1). }\end{array}$ \\
\hline Task complexity & $\begin{array}{l}\text { Number of client subsidiaries across the globe } \\
\text { that is simultaneously involved in the same } \\
\text { outsourced venture with one supplier. (The } \\
\text { synergies among multiple cultural and political } \\
\text { entities increases task complexity, because } \\
\text { more resources must be dedicated to procedures } \\
\text { to facilitate seamless coordination that spans } \\
\text { client subsidiaries, client headquarters, and } \\
\text { their common supplier) }\end{array}$ & $\begin{array}{l}\text { Data range, } \\
\quad 1-22\end{array}$ & $\begin{array}{l}\text { "BT today announced a new 5-year outsourcing contract } \\
\text { with Honeywell. The deal will see BT manage and } \\
\text { deliver communications and networking services to } \\
\text { Honeywell sites throughout } 15 \text { European countries" (PR } \\
\text { Newswire 2003) (coded } 15 \text { for } 15 \text { Honeywell } \\
\text { subsidiaries) } \\
\text { "Merrill Lynch has completed a } 3 \text { year agreement to } \\
\text { outsource all fund accounting and daily pricing services } \\
\text { for its US retail mutual funds to State Street Corp." } \\
\text { (Business Wire 2001) (coded 1). }\end{array}$ \\
\hline $\begin{array}{l}\text { Ex ante supplier- } \\
\text { related uncertainty } \\
\text { Prior relationships } \\
\text { with supplier }\end{array}$ & $\begin{array}{l}\text { Number of prior outsourcing contracts with the } \\
\text { supplier selected in the current outsourcing } \\
\text { announcement. These prior contracts are } \\
\text { unrelated to the current contract. }\end{array}$ & $\begin{array}{l}\text { Data range, } \\
0-3\end{array}$ & $\begin{array}{l}\text { "ACS has been a valued BPO provider for more than } \\
4 \text { years providing accounts payable and document } \\
\text { management services. In a new deal ACS will provide } \\
\text { Office Depot with accounts receivables functions for a } \\
\text { year" (Business Wire 2003). No other outsourcing } \\
\text { announcement between Office Depot and ACS was } \\
\text { found in the database (coded } 1 \text { ). }\end{array}$ \\
\hline $\begin{array}{l}\text { Ex post supplier- } \\
\text { related uncertainty } \\
\text { Length of contract }\end{array}$ & Length of contract in years & $\begin{array}{l}\text { Data range, } \\
\quad 1-10\end{array}$ & $\begin{array}{l}\text { "EDS and Bank of America today announced they signed } \\
\text { a } 10 \text { year } \$ 4.5 \text { billion managed network outsourcing } \\
\text { services agreement. EDS will help Bank of America } \\
\text { transform its voice and data network infrastructure by } \\
\text { providing the company with stronger and more flexible } \\
\text { operating platforms" (PR Newswire 2002) (coded 10). }\end{array}$ \\
\hline $\begin{array}{l}\text { Performance ambiguity } \\
\text {-Intangibility of } \\
\text { outsourcing goal }\end{array}$ & \multicolumn{2}{|l|}{$\begin{array}{l}\text { The metrics depend on the goal and the nature of the } \\
\text { function. For example, quality improvements to } \\
\text { business processes such as customer service may } \\
\text { be objectively measured using customer satisfaction } \\
\text { indices; quality improvements for IT infrastructure } \\
\text { management may be only subjectively assessed. } \\
\text { Two expert judges read the announcements, } \\
\text { considered both the stated goal and the outsourced } \\
\text { task, and then coded the intangibility of an } \\
\text { outsourcing goal on a scale of } 1 \text { to } 5 \text {, in } \\
\text { increasing order. We used the average of the } \\
\text { ratings by the two expert coders. Inter-rater } \\
\text { reliability score was } 0.81 \text {. }\end{array}$} & $\begin{array}{l}\text { "General Motors Corp. announced a definitive 5-year } \\
\text { outsourcing agreement to improve operational } \\
\text { flexibility. Under the agreement, Arvato services, Inc. } \\
\text { will provide General Motors with services including } \\
\text { fulfillment, lettershop, print on demand services, } \\
\text { inventory and procurement management and postal } \\
\text { optimization and consolidation services from its state of } \\
\text { the art logistics and customer care center in Duncan, } \\
\text { South Carolina" (Information Week 2003) (coded } 5 \\
\text { because flexibility is not easily quantifiable). } \\
\text { Announcement in "CBS has positioned the outsourcing } \\
\text { contract with SMS as part of an overall strategic } \\
\text { business program ... CBS will transfer day-to-day } \\
\text { management of its data processing operations to SMS } \\
\text { so that it can focus on bottom-line objectives to lower } \\
\text { costs and improve the company's overall operating } \\
\text { efficiencies" (Business Wire 1997) (coded } 1 \text { because } \\
\text { efficiencies are quantifiable). }\end{array}$ \\
\hline $\begin{array}{l}\text { Controls: industry } \\
\text { concentration, } \\
\text { client firm size }\end{array}$ & $\begin{array}{l}\text { Herfindahl's index and the average share } \\
\text { price } \times \text { number of shares outstanding over } \\
\text { the event period [8], } \$ \text { Sales (in millions) }\end{array}$ & & $\begin{array}{l}\text { We square the market share of all firms in an industry in } \\
\text { a year, then sum those squares. }\end{array}$ \\
\hline
\end{tabular}

price $\times$ number of shares outstanding ove 
this event window as the dependent variable in our regression equation. Multicollinearity does not seem to be an issue; the highest variance inflation factor is 3.20 (smaller than 10). We discuss the results for the regression with mean CAR $(0,+1)$ as the dependent variable; the results are statistically equivalent when we use mean $\operatorname{BHAR}(0,+1)$ as dependent variable as well.

Because localized outsourcing represents our base mode, we compare it with onshore outsourcing and global outsourcing. If the coefficients related to onshore outsourcing (global outsourcing) are positive, the abnormal stock returns for onshore outsourcing (global outsourcing) are higher than those for localized outsourcing, such that shareholders prefer onshore (global) to localized outsourcing. To compare onshore outsourcing and global outsourcing, we conducted Wald tests with the relevant coefficients. ${ }^{6}$ Finally, though we included all the main and interaction effects in a single regression; for ease of presentation, we display the results separately in Table 3a-c.

\subsection{Main Effects of Outsourcing Modes}

The main effect of global outsourcing is positive and statistically significant ( $b=9.48, p<0.05$ ); shareholders prefer global over localized outsourcing (see Table 3a). The main effect of onshore outsourcing is not statistically significant $(b=8.01$, $p>0.69$ ). In a Wald test, we find that shareholders seem to favor global outsourcing over onshore outsourcing $(w=-1.47$, $p<0.10$ ).

Although the coefficient of the sample selection correction parameter is not statistically significant $\left(\lambda_{i}^{S S}=40.21, p>0.58\right)$, both the endogeneity correction parameters are statistically significant $\left(\lambda_{i}^{\text {on }}=-22.49, p<0.01 ; \lambda_{i}^{\text {global }}=10.39, p<0.05\right)$. Thus, shareholders appear cognizant of the factors that managers take into account when choosing a specific outsourcing mode.

\subsection{Hypotheses Tests}

\subsubsection{Task Complexity}

We suggested in Hypothesis 1 that as task complexity increases, shareholders would rank onshore outsourcing first, followed by global outsourcing and then localized outsourcing. However, as we show in Table $3 \mathrm{~b}$, the only statistically significant result is that shareholders favor global outsourcing ( $b=2.56, p<0.05$; Table $3 b)$ over localized outsourcing. Therefore, Hypothesis 1 is supported partially.

\footnotetext{
${ }^{6}$ For example, if we lay out our model with the main effects of interest, such that $\mathrm{CAR}=b_{0}+b_{1} \times$ onshore outsourcing $+b_{2} \times$ global outsourcing, the Wald coefficient becomes $\left(b_{1}-b_{2}\right)$, and its standard error is calculated by $\sqrt{\frac{\left(\text { variance }\left(b_{1}\right)+\text { variance }\left(b_{2}\right)-2 \times \text { covariance }\left(b_{1}, b_{2}\right)\right.}{1}} 185$ (Greene 2002).
}

\subsubsection{Ex Ante Supplier-Related Uncertainty}

For the test of Hypothesis 2, which predicts that lower ex ante supplier-related uncertainty increases preferences for localized outsourcing but decreases preferences for onshore outsourcing, we note that a negative coefficient of interaction between prior relationships with the bidding supplier and onshore outsourcing would indicate lower preference for onshore outsourcing than for localized outsourcing in cases of lower ex ante supplier-related uncertainty. We interpret the coefficients of interaction between the measures of ex ante supplier-related uncertainty and global outsourcing similarly.

As we show in Table 3c, we find support for this hypothesis. The coefficient of interaction between prior relationships with the bidding supplier and onshore outsourcing $(b=-3.51$, $p<0.10)$ is negative and statistically significant. The Wald test between the coefficients of the interactions of prior relationships with the bidding supplier with both onshore outsourcing and global outsourcing is negative and statistically significant $(w=-0.95, p<0.05)$. Finally, the coefficient of interaction between prior relationships and global outsourcing is negative and statistically significant $(b=-2.56, p<0.01)$.

\subsubsection{Ex Post Supplier-Related Uncertainty}

As ex post supplier-related uncertainty increases (measured as the length of the contract), shareholders should prefer onshore outsourcing most and localized outsourcing least. As we show in Table 3c, we do not find support for Hypothesis 3a, because the coefficient of interaction between length of contract and onshore outsourcing is not statistically significant $(b=-2.23$, $p>0.91$ ). For Hypothesis $3 b$, the Wald test with length of contract and onshore versus global outsourcing reveals that global outsourcing is preferred over onshore outsourcing ( $w=-14.04$, $p<0.05$ ) - the opposite of our prediction. However, we find support for Hypothesis $3 \mathrm{c}$, in that the coefficient of interaction between length of contract and global outsourcing is positive and statistically significant $(b=11.81, p<0.01)$, so shareholders prefer global to localized outsourcing. As ex post supplierrelated uncertainty increases, shareholders prefer global outsourcing most, and they do not seem to differentiate between onshore outsourcing and localized outsourcing.

\subsubsection{Performance Ambiguity}

Finally, we have hypothesized that as performance ambiguity (in terms of the intangibility of outsourcing goals) increases, shareholders should prefer onshore outsourcing most and localized outsourcing least. We find support for Hypothesis $4 \mathrm{a}$ because the coefficient of interaction between intangibility of outsourcing goals and onshore outsourcing is positive and statistically significant $(b=8.35, p<0.01)$. We do not find support for Hypothesis $4 \mathrm{~b}$ though; the Wald test with the 
Table 2 Descriptive statistics and bivariate correlation coefficients

\begin{tabular}{|c|c|c|c|c|c|c|c|c|c|c|c|}
\hline & Mean (s.d.) & (1) & $(2)$ & (3) & (4) & $(5)$ & (6) & (7) & (8) & (9) & $(10)$ \\
\hline $\operatorname{CAR}(0,+1)$ & $-2.04(56.13)$ & & & & & & & & & & \\
\hline Localized outsourcing (2) & $0.35(0.26)$ & -0.19 & & & & & & & & & \\
\hline Global outsourcing (3) & $0.38(0.51)$ & $0.24^{\mathrm{a}}$ & -0.33 & & & & & & & & \\
\hline Onshore outsourcing (4) & $0.27(0.41)$ & $-0.18^{\mathrm{b}}$ & -0.35 & -0.74 & & & & & & & \\
\hline Task complexity, geographic scope (5) & $5.32(42.96)$ & 0.04 & $0.27^{\mathrm{a}}$ & -0.02 & -0.14 & & & & & & \\
\hline Ex ante supplier-related uncertainty, prior relationships (6) & $1.12(0.42)$ & -0.04 & 0.09 & 0.07 & -0.14 & 0.03 & & & & & \\
\hline Ex post supplier-related uncertainty, length of contract (7) & $4.05(0.71)$ & -0.05 & $-0.12^{\mathrm{a}}$ & -0.13 & 0.15 & -0.13 & 0.13 & & & & \\
\hline $\begin{array}{l}\text { Performance ambiguity, intangibility of } \\
\text { outsourcing goal (8) }\end{array}$ & $3.30(7.68)$ & -0.05 & -0.05 & 0.13 & -0.09 & -0.01 & -0.01 & -0.01 & & & \\
\hline Client firm size (9) & $33.51(58.70)$ & $0.29^{\mathrm{a}}$ & -0.02 & 0.01 & 0.00 & -0.01 & -0.04 & $0.14^{\mathrm{b}}$ & 0.07 & & \\
\hline Industry concentration (10) & $0.27(0.33)$ & 0.05 & -0.05 & 0.07 & -0.03 & 0.05 & 0.05 & -0.09 & 0.06 & -0.11 & \\
\hline
\end{tabular}

s.d. standard deviation

${ }^{\text {a }}$ Significant at $5 \%$

${ }^{\mathrm{b}}$ Significant at $10 \%$

intangibility of outsourcing goals, onshore outsourcing, and global outsourcing is not statistically significant ( $w=0.73$, $p>0.19$ ). In support of Hypothesis $4 c$, the coefficient of interaction between intangibility of outsourcing goals and global outsourcing is positive and statistically significant $(b=7.62$, $p<0.01)$. As performance ambiguity increases, in comparison with localized outsourcing, shareholders prefer onshore or global outsourcing; however, there is no difference in preference between onshore and global outsourcing.

\section{Discussion}

We examine the geographic location of the outsourced task as a key determinant of the extent of relational governance achievable in outsourced ventures of Fortune 500 multinational corporations. Three modes of outsourcing (localized, global, and onshore outsourcing) vary in the extent of relational governance they allow, so these outsourcing modes should be aligned to the governance needs of the outsourced ventures. We use transaction cost economics to conceptualize the outsourced venture in terms of task complexity, supplierrelated uncertainty, and performance ambiguity.

Overall, localized outsourcing is not the most popular option, likely due to the barriers that geographical, cultural, political, and legal distances pose (e.g., [54]). This result also vindicates anecdotal evidence about the societal misgivings that arise in response to localized outsourcing, including the potential for higher unemployment rates domestically, wage compression, organizational concerns, security risks, and knowledge misappropriation by foreign suppliers. The only time shareholders are overwhelmingly in favor of localized outsourcing is when the contracts are with known suppliers. Prior relationships with suppliers provide enough knowledge about the suppliers' capabilities and commitment to allay concerns and warrants focus on production efficiencies.

Unlike localized and onshore outsourcing, global outsourcing seems preferable for multiple types of outsourced ventures. Quite unexpectedly, we find that though the need for relational governance is high when task complexity increases, global outsourcing rather than onshore outsourcing is most preferred. This result may be an artifact of our operationalization of task complexity. When the geographic scope of the outsourced process spans multiple client subsidiaries across the globe, onshore outsourcing loses some relevance, because by definition, onshore outsourcing requires the supplier to operate from every country in which a client subsidiary exists. Such multiple co-locations are unlikely to be economically viable, such that onshore outsourcing is not a likely option. To manage operations in multiple sites, global outsourcing appears to be the best option. Suppliers such as Syntel and Electronic Data Services (now part of HewlettPackard) maintain subsidiaries in multiple countries, which often enable them to ensure their presence in most client sites, even as the geographic scope of the outsourced venture increases. Such overlaps between multiple client sites and supplier locations create opportunities for information exchange, frequent communication, and shared implicit behavioral norms across different countries.

Contrary to our hypotheses, even with greater uncertainty about a supplier's long-term actions with a longer outsourcing contract, shareholders prefer global outsourcing over onshore outsourcing, even though the latter seemingly would provide more relational governance benefits. Perhaps these clients are concerned about supplier-related long-term uncertainties but also value flexibility for future contract adaptations. Global outsourcing can be easily scaled down by the supplier to either an onshore or an offshore implementation, then scaled back up 
Table 3 The main and interaction effects in a single regression
The base case is localized outsourcing. Therefore, all coefficients are interpreted relative to localized outsourcing. All the main and interaction effects are the results of a single regression. Results in italics are discussed in the text

MAM market-adjusted model

${ }^{a}$ Significant at $1 \%$

${ }^{\mathrm{b}}$ Significant at $5 \%$

${ }^{\mathrm{c}}$ Significant at $10 \%$

\begin{tabular}{|c|c|c|c|}
\hline & \multirow[t]{2}{*}{ Independent variables } & \multicolumn{2}{|l|}{ D. V. } \\
\hline & & $\begin{array}{l}\text { Mean } \\
\text { CAR }(0,+1) \\
\text { MAM }\end{array}$ & $\begin{array}{l}\text { Mean } \\
\text { BHAR }(0,+1) \\
\text { MAM }\end{array}$ \\
\hline \multicolumn{4}{|c|}{ Main effects of modes of outsourcing and control variables } \\
\hline Constant & Constant & $-18.21^{\mathrm{a}}(7.39)$ & $-15.10^{\mathrm{a}}(6.93)$ \\
\hline \multirow[t]{2}{*}{ Modes } & Onshore outsourcing & $8.01(16.66)$ & $7.22(5.62)$ \\
\hline & Global outsourcing & $9.48^{\mathrm{b}}(4.81)$ & $7.08^{\mathrm{b}}(3.57)$ \\
\hline Sample selection correction & $\lambda_{i}^{\mathrm{ss}}$ & $40.21(62.97)$ & $37.13(32.23)$ \\
\hline Endogeneity correction & $\lambda_{i}^{\text {on }}$ & $-22.49^{\mathrm{a}}(8.30)$ & $-21.55^{\mathrm{a}}(9.32)$ \\
\hline Endogeneity correction & $\lambda_{i}^{\text {global }}$ & $10.39^{b}(4.88)$ & $10.23^{\mathrm{a}}(4.06)$ \\
\hline \multirow[t]{2}{*}{ Controls } & Client size & $26.01(24.98)$ & $34.23(34.75)$ \\
\hline & Industry concentration & $-1.37(8.35)$ & $-3.38(28.41)$ \\
\hline$R^{2}$ in total regression & & 0.384 & 0.304 \\
\hline \multicolumn{4}{|l|}{ Testing hypothesis 1} \\
\hline & Task complexity (TCG) & $-7.22(32.64)$ & $-7.21(7.91)$ \\
\hline & Onshore outsourcing $\times \mathrm{TCG}$ & $-0.65(1.80)$ & $-0.81(1.46)$ \\
\hline & Global outsourcing $\times \mathrm{TCG}$ & $2.56^{\mathrm{b}}(1.20)$ & $2.39^{\mathrm{b}}(1.19)$ \\
\hline \multicolumn{4}{|l|}{ Testing hypotheses $2-4$} \\
\hline \multirow{3}{*}{$\begin{array}{l}\text { Ex ante supplier-related } \\
\text { uncertainty }\end{array}$} & Prior relationships with supplier & $7.03(24.46)$ & $7.49(24.50)$ \\
\hline & Onshore outsourcing $\times$ prior relationships & $-3.5 I^{\mathrm{C}}(1.93)$ & $-4.01^{\mathrm{b}}(1.86)$ \\
\hline & Global outsourcing $\times$ prior relationships & $-2.56^{b}(1.27)$ & $-3.12^{\mathrm{b}}(1.61)$ \\
\hline \multirow{3}{*}{$\begin{array}{l}\text { Ex post supplier-related } \\
\text { uncertainty }\end{array}$} & Length of contract & $3.32(3.67)$ & $3.01(2.53)$ \\
\hline & Onshore outsourcing $\times$ length of contract & $-2.23(5.08)$ & $-2.0 .25(5.12)$ \\
\hline & Global outsourcing $\times$ length of contract & $11.81^{\mathrm{a}}(4.58)$ & $11.97^{\mathrm{a}}(5.50)$ \\
\hline \multirow[t]{3}{*}{ Performance ambiguity } & Intangibility of outsourcing goal & $-1.08^{\mathrm{C}}(0.54)$ & $-1.18^{\mathrm{c}}(0.59)$ \\
\hline & $\begin{array}{l}\text { Onshore outsourcing } \times \text { intangibility } \\
\text { of outsourcing goal }\end{array}$ & $8.35^{\mathrm{a}}(2.82)$ & $8.05^{\mathrm{a}}(3.07)$ \\
\hline & $\begin{array}{l}\text { Global outsourcing } \times \text { intangibility } \\
\text { of outsourcing goal }\end{array}$ & $7.62^{\mathrm{a}}(3.01)$ & $7.16^{\mathrm{a}}(2.87)$ \\
\hline
\end{tabular}

if necessary. In comparison, an outsourced venture that began as an onshore venture may require considerable time and effort to expand the scale of operations to global levels while also expanding the scope of existing programs and processes. If the existing supplier lacks appropriate global delivery capabilities for accommodating the expanding scale of the task, the client may need to switch suppliers - a costly exercise. Thus, global outsourcing provides dual benefits of relational governance and high flexibility; onshore outsourcing only provides the benefit of relational governance.

Our results corroborate our proposition that outsourced ventures with intangible outsourcing goals require high degrees of relational governance to ensure that suppliers maintain operating standards and adhere to contractual guidelines. Although the obvious choice seems to be onshore outsourcing, shareholders do not really differentiate between onshore and global outsourcing, which reinforces the notion of multiple resource-based advantages of global outsourcing. A global outsourcing mode, with its significant onshore and offshore presence, can access top talent around the world. The use of diverse physical and human resources in global outsourcing also provides access to diverse stocks of knowledge. Coordinating such diversity to implement a task creates immense possibilities for improvements and innovative inputs.

\subsection{Limitations}

As do most researchers, we focus on a small set of theoretically derived factors that are potentially relevant. It was not possible to increase the number of independent constructs because we were limited to information available in outsourcing announcements. Factors such as contract size and supplier reputation are also theoretically important. Our sample of announcements contains limited information about suppliers; thus including supplier details in this analysis was not feasible. However, incorporating market assessments of the suppliers' capabilities to explain abnormal returns 
associated with different modes of outsourcing would provide an interesting topic for further research. Another limitation reflects the number of announcements for each mode of outsourcing, though our total observation size (185 outsourcing events) is reasonable. Event studies, with their strict rules for announcement collection and filtering, are prone to low observation sizes, with samples typically less than 200 (e.g., [42, 47]). As the observation size decreases, the possibility of type II errors due to inflated standard errors increases; therefore, our finding of statistically significant results suggests that our results are conservative estimates of the true effects.

Acknowledgments The research was made possible by support from the Institute of the Study of Business Markets located at the Smeal College of Business, Pennsylvania State University, University Park, PA, 16802, USA.

\section{References}

1. Al-Khalifa AK, Peterson SE (2004) On the relationship between initial motivation, and satisfaction and performance in joint ventures. Eur J Mark 38(1/2):150-174

2. Argyres N (1996) Evidence on the role of firm capabilities in vertical integration decisions. Strateg Manag J 17:129-150

3. Aubert BA, Patry M, Rivard S (2006) Measuring and managing IT outsourcing risk: lessons learned. Springer, Berlin

4. Bertrand O (2011) What goes around, comes around: effects of offshore outsourcing on the export performance of firms. J Int Bus Stud 42(2):334-344

5. Beulen E, Fenema PV, Currie W (2005) From application outsourcing to infrastructure management: extending the offshore outsourcing service portfolio. Eur Manag J 23(2):133-144

6. Cannon JP, Achrol RS, Gundlach GT (2000) Contracts, norms, and plural form governance. J Acad Mark Sci 28(2):180-194

7. Carson SJ, Madhok A, Wu T (2006) Uncertainty, opportunism, and governance: The effects of volatility and ambiguity on formal and relational contracting. Acad Manag J 49(5):1058-1077

8. Chan HS, Kensinger JW, Keown AJ, Martin JD (1997) Do strategic alliances create value? J Financ Econ 46:199-221

9. Coles JW, Hesterly WS (1998) The impact of firm-specific assets and the interaction of uncertainty: an examination of make or buy decisions in public and private hospitals. J Econ Behav Organ 36(3):383409

10. Conlon EJ, Parks JM (1990) Effects of monitoring and tradition on compensation arrangements: an experiment with principal-agent dyads. Acad Manag J 33(3):603-622

11. Couto V, Mani M, Lewin AY, Peeters C (2006) The globalization of white-collar work: the facts and fallout of next-generation offshoring. Fuqua School of Business Booz/Allen/Hamiltion and Offshoring Research Network, New York

12. Crocker KJ, Masten SE (1991) Pretia ex machina? Prices and process in long-term contracts. J Law Econ 34(1):69-99

13. Das TK, Teng B-S (1998) Between trust and control: developing confidence in partner cooperation in alliances. Acad Manag Rev 23(3):491-512

14. David RJ, Han S-K (2004) A systematic assessment of the empirical support for transaction cost economics. Strateg Manag J 25(1):39-58
15. Di Gregorio D, Musteen M, Thomas DE (2009) Offshore outsourcing as a source of international competitiveness for SMEs. J Int Bus Stud 40:969-988

16. Ferguson RJ, Paulin M, Bergeron J (2005) Contractual governance, relational governance, and the performance of interfirm service exchanges: The influence of boundary-spanner closeness. J Acad Mark Sci 33(2):217-234

17. George, B. and R. Hirschheim (2007). The offshore outsourcing landscape: historical development and challenges for the IS discipline. In: Aubert, B.A. (eds). Information technology outsourcing. Sharpe: Armonk, NY. pp 305-322

18. Ghoshal S, Moran P (1996) Bad for practice: a critique of the transaction cost theory. Acad Manag Rev 21(1):13-47

19. Grant R (1996) Toward a knowledge base theory of the firm. Strateg Manag J 17(Special Issue):109-122

20. Greene WH (2002) Econometric analysis, 5th edn. Prentice-Hall, Upper Saddle River, NJ

21. Gubbi S, Aulakh P, Ray S, Sarkar M, Chittoor R (2010) Do international acquisitions by emerging-economy firms create shareholder value: the case of Indian firms. J Int Bus Stud 41(3):397-418

22. Hall JA (2005) Financial performance, CEO compensation, and large-scale information technology outsourcing decisions. J Manag Inf Syst 22(1):193-221

23. Hawk S, McHenry W (1995) The maturation of the Russian offshore software industry. Inf Technol Dev 11(1):31-57

24. Heckman JJ (1979) Sample selection bias as a specification error. Econometrica 47:153-161

25. Heide JB (1994) Interorganizational governance in marketing channels. J Mark 58:71-85

26. Henderson GV Jr (1990) Problems and solutions in conducting event studies. J Risk Ins 57(2):282-306

27. Henisz W (2000) The institutional environment for institutional investment. J Law Econ Org 16(2):334-364

28. Henisz WJ, Williamson OE (1999) Comparative economic organization - within and between countries. Bus Polit 1(3):261-277

29. Herbsleb JD, Mockus A (2003) An empirical study of speed and communication in globally distributed software development. IEEE Trans Softw Eng 29(6):481-494

30. Johnson J, Tellis G (2008) Drivers of success for market entry into China and India. J Mark 72:1-13

31. Johnson SA, Houston M (2000) Buyer-supplier contracts versus joint ventures: determinants and consequences of transaction structure. J Mark Res 37(1):1-15

32. Kay J (1993) The economics of intellectual property rights. Int Rev Law Econ 13:337-348

33. Keil P (2005) Principal agent theory and its application to analyze outsourcing of software development. Proceedings of the Seventh International Workshop on Economics-driven Software Engineering Research. ACM, St. Louis, Missouri

34. Kenney M, Massini S, Murtha TP (2009) Offshore administrative and technical work: new fields for understanding the global enterprise. J Int Bus Stud 40:887-900

35. Kleindorfer PR, Wu DJ (2003) Integrating long and short term contracting via business-to-business exchanges for capital-intensive industries. Manag Sci 49(11):1597-1615

36. Kumar K, van Fenema PC, von Glinow MA (2009) Offshoring and the global distribution of work: implications for task interdependence theory and practice. J Int Bus Stud 40:642-667

37. Larson A (1992) Network dyads in entrepreneurial settings: a study of the governance of exchange relationships. Adm Sci Q 37(1):76-104

38. Lohr, S. (Jan 8, 2009). http://www.nytimes.com/2009/01/09/ business/09react.html

39. Lusch RF, Brown JR (1996) Interdependency, contracting, and relational behavior in marketing channels. J Mark 60(4):19-38

40. Mackinlay AC (1997) Event studies in economics and finance. J Econ Financ 35:159-174 
41. Masten SE, Crocker KJ (1985) Efficient adaptation in long-term contracts: take-or-pay provisions for natural gas. Am Econ Rev 775(5): 1083-1093

42. Meschi P-X (2005) Stock market valuation of joint venture sell-offs. J Int Bus Stud 36:688-700

43. Mishina Y, Pollock TG, Porac JF (2004) Are more resources always better for growth? Resource stickiness in market and product expansion. Strateg Manag J 25(12):1179-1197

44. Nemiro JE (2000) The glue that binds creative virtual teams. Idea Group Publishing, Hershey, PA

45. Noordewier TG, John G, Nevin JR (1990) Performance outcomes of purchasing arrangements in industrial buyer-vendor relationships. $\mathrm{J}$ Mark 54(4):80-93

46. Novak S, Eppinger SD (2001) Sourcing by design: product complexity and the supply chain. Manag Sci 47(1):189-204

47. Ojah K, Monplaisir L (2003) Investors' valuation of global product design and development. J Int Bus Stud 34:457-472

48. Oshri L, Kotlarsky J, Willcocks LP (2009) The handbook of global outsourcing and Offshoring. Macmillan, New York, NY

49. Philip, T., G. Schwabe and E. Wende (2010). Identifying early warning signs of failures in offshore software development projects - a Delphi survey. AMCIS Proceeding, p. 462

50. Poppo L, Zenger T (2002) Do formal contracts and relational governance function as substitutes or complements? Strateg Manag J 23:701-725

51. Reus T, Lamont B (2009) The double-edged sword of cultural distance in international acquisitions. J Int Bus Stud 40(8):1298-1316
52. Rindfleisch A, Heide JB (1997) Transaction cost analysis: past, present, and future applications. J Mark 61(4):30-54

53. Robinson M, Kalakota R (2004) Offshore outsourcing: business models, ROI and best practices. Mivar Press, Alpharetta, GA

54. Sarker S, Sahay S (2004) Implications of space and time for distributed work: an interpretive study of US-Norwegian systems development teams. Eur J Inf Syst 13(1):3-20

55. Savitz E (2012) The road ahead: gartner's outlook for 2012 and beyond. http://www.forbes.com/sites/ericsavitz/2011/12/01/theroad-ahead-gartners-outlook-for-2012-and-beyond/

56. Stump RL, Heide, JB (1996) Controlling supplier opportunism in industrial relationships. J Mark Res 33(4):431-441

57. Taylor H (2006) Critical risks in outsourced IT projects: the intractable and the unforseen. Commun ACM 49(11):75-80

58. Thompson HST, Yu Y (2005) Online buying behavior: a transaction cost economics perspective. Omega 33(5):451-465

59. Yu C-MJ, Liao T-J, Lin Z-D (2006) Formal governance mechanisms, relational governance mechanisms, and transaction-specific investments in supplier-manufacturer relationships. Ind Mark Manag 35(2): 128-139

60. Varadarajan R (2012) B2B relationship underpinnings of outsourcing. In: Lilien GL, Grewal R (eds) Handbook of business-to-business marketing. Edward Elgar, Cheltenham, UK, pp 400-416

61. Williamson OE (1993) Calculativeness, trust, and economic organization. J Law Econ 36:453-486 